\title{
Detection and Serological Characterization of Rice Yellow Mottle Virus in Central African Republic
}

\author{
Régis Dimitri Sokpé Longué ${ }^{1,2 *}$, Innocent Zinga², Silla Semballa², Nicolas Barro³, Oumar Traoré1 \\ ${ }^{1}$ Crop Production Department, Institute of Environment and Agricultural Research, Ouagadougou, Burkina Faso \\ ${ }^{2}$ Life Science Department, University of Bangui, Bangui, Central African Republic \\ ${ }^{3}$ Department of Biochemistry and Microbiology, University of Ouagadougou I-Professor Joseph Ki-Zerbo, Ouagadougou, Burkina Faso \\ Email: *regislongue@yahoo.fr
}

How to cite this paper: Longué, R.D.S., Zinga, I., Semballa, S., Barro, N. and Traoré, O. (2016) Detection and Serological Characterization of Rice Yellow Mottle Virus in Central African Republic. Agricultural Sciences, 7, 911-919.

http://dx.doi.org/10.4236/as.2016.712082

Received: November 24, 2016

Accepted: December 26, 2016

Published: December 29, 2016

Copyright $\odot 2016$ by authors and Scientific Research Publishing Inc. This work is licensed under the Creative Commons Attribution International License (CC BY 4.0).

http://creativecommons.org/licenses/by/4.0/

\begin{abstract}
Serological and biological detection of Rice Yellow Mottle Virus (RYMV) in leaf samples belonging from cultivated rice species and wild grasses revealed 201 positive detections. All these isolates occurred exclusively on cultivated rice species (Oryza sati$v a$ L. and $O$. glaberrima Steud). A relationship was found between cultural practices and presence of RYMV in fields $\left(\chi^{2}=108.83, \mathrm{df}=1, \mathrm{P}<0.001\right)$. The serological characterization using Monoclonal antibodies (Mabs $\mathrm{A}$ and $\mathrm{D}$ ), showed homogenous reaction with Mabs A alone. These results indicated that Ser1 serotype is present in the south of Central African Republic.
\end{abstract}

\section{Keywords}

RYMV, Detection, Serological Characterization, Central African Republic

\section{Introduction}

Rice (Oryza sativa L.) is one of the most important cereals in the world. It is an important food crop and a source of revenue for farmers in Africa. Rice has gradually become one of the major cereal productions in Central African Republic (CAR) where it contributes to fight against food insecurity. However, rice production is severely affected by Rice Yellow Mottle Virus (RYMV), the most important viral disease of rice in Africa. Member of genus Sobemovirus, RYMV was the first reported in Kenya in East Africa [1]. RYMV was found in most countries where rice is growing and also in the islands of Zanzibar and Madagascar [2] [3] and more recently in Chad, Cameroon, Central African Republic and Democratic Republic of Congo [4].

The virus induced symptoms that include yellowing and mottling, reduced tillering and sterility of flowers. RYMV is mechanically transmissible and is naturally transmit- 
ted mainly by chrysomelid beetles. It can also be transmitted by mammals such as cows, grass rats or donkeys [5]. Disease caused yield loss ranges from $25 \%$ to $100 \%$ depending on the rice genotype, date of infection and the virus isolates.

Variability in RYMV isolates has been reported and revealed five main serotypes in West, Central Africa (Ser1 to Ser3) and East Africa (Ser4 and Ser5) [6] [7]. For this study, we investigate the presence of RYMV in several sites around Bangui and further south which benefit from forest climate (up to $1500 \mathrm{~mm}$ rainfall per year). Natural and experimental hosts of the virus are taken into account to establish the role of wild grasses in the virus epidemiology in the country. We also analyze the variability of isolates at serological level to compare later with molecular typing.

\section{Material and Methods}

\subsection{Survey and the Collect of Leave Samples}

Between 2012 and 2015, a survey was performed in the south of CAR in several localities bordering Bangui city and other locations further in the south at $75 \mathrm{~km}$ from the capital (Figure 1). Leaves samples were harvested from cultivated rice and wild grass including Oryza species in lowland, upland and irrigated conditions (Table 1) and processed as indicated by Konate et al. [8]. Wild grasses were identified using a document entitled "weeds of rice in West Africa" [9]. The visual diagnostic of RYMV are yellowing and mottling of leaves as well as severe stunting in some rice genotypes [10]. Thus, leaves were collected based on these typical symptoms (Figure 2) of RYMV using plastic bags. Samples were labeled with name location and ecological condition and they were stored in the ice box. Thereafter, samples were transferred to the laboratory and stored in the freezer at $-20^{\circ} \mathrm{C}$ for further processing.

\subsection{Biological Tests}

Typical symptoms of rice yellow mottle disease could be wrongly attributed to iron or nitrogen deficiency. Therefore, the mechanical transmission test was done using the susceptible rice variety IR64 to confirm RYMV transmission. Leaf samples from fields were ground in the mortar at the ratio of 1:10 (w/v) with $0.01 \mathrm{M}$ phosphate buffer and $\mathrm{pH}$ 7.0. The powder of carborundum (600 mesh) was added to the extracts, which were rubbed onto leaves of 2 week-old seedlings [11] [12] [13]. All experiment was conducted in a greenhouse under insect proof conditions.

\subsection{Serological Detection of RYMV}

The presence of RYMV in the collected samples was confirmed using DAS-ELISA (double antibody sandwich enzyme_linked immunosorbent assay) method [14]. A polyclonal antibody raised against isolates from Madagascar known to react strongly with isolates from west and Central Africa was used as coating antibody [6]. It was kindly offered by the Doctor Denis Fargette (IRD, Montpellier, France). All procedures of the test were as previously described [8].

Leaf samples $(1 \mathrm{~g}$ ) were ground in $10 \mathrm{ml}$ PBS buffer (Phosphate buffered saline $\mathrm{pH}$ 


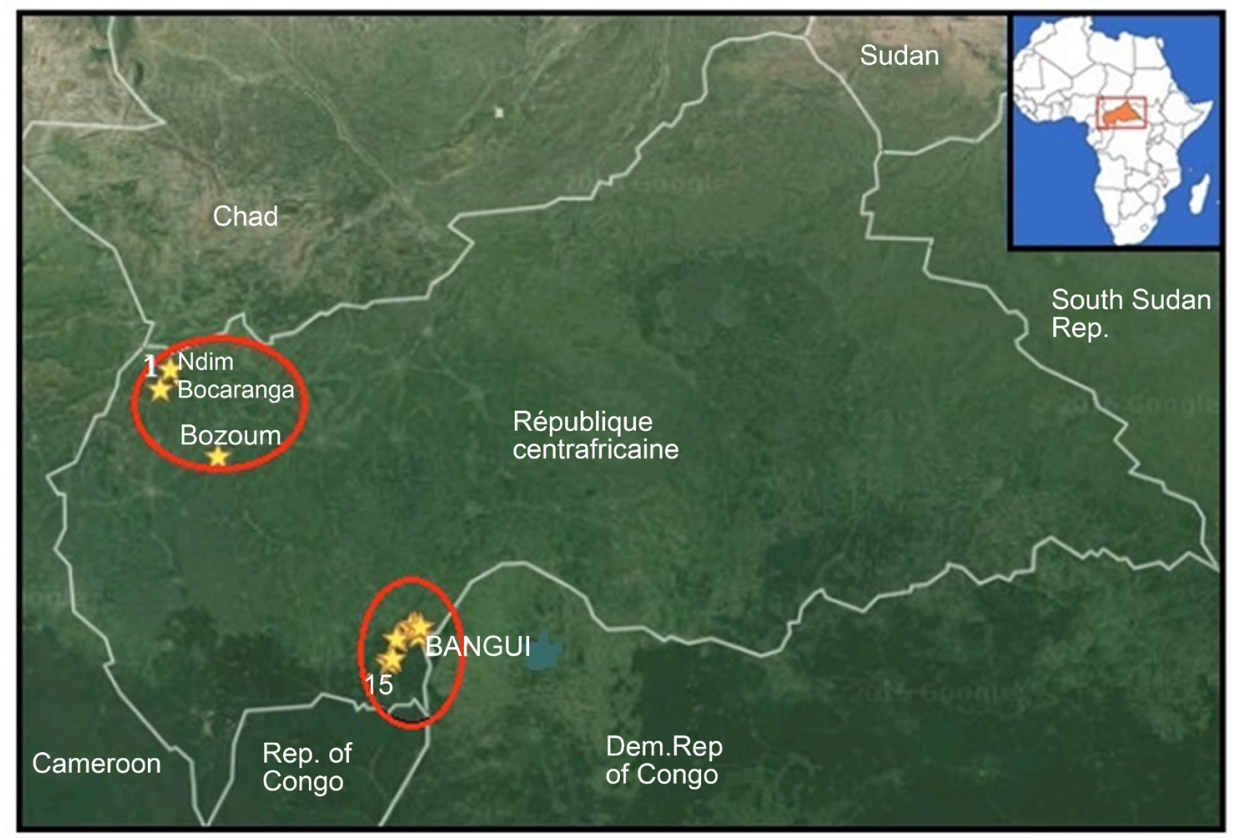

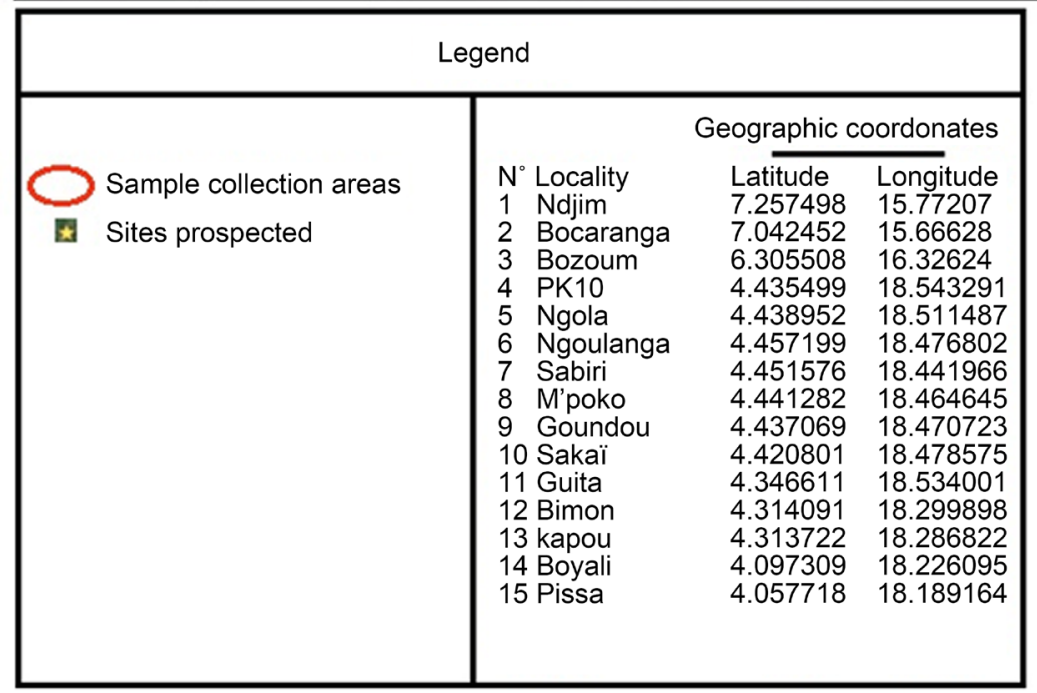

Figure 1. Map of the part of the country where survey was done. Sites prospected are numbered from 1 to 15 with corresponding geographic coordinates.

7.4) containing $0.05 \%$ of tween 20 (PBS-T) and $2 \%$ polyvinylpyrolidone (PVP) or extraction buffer. The resulting extracts were centrifuged for $10 \mathrm{~min}$ at $8000 \mathrm{rpm}$ at $4^{\circ} \mathrm{C}$. The procedure was the following: immunoplates were coated with $5 \mu \mathrm{g} / \mathrm{ml} \mathrm{IgGs} \mathrm{an-}$ ti-RYMV in $5 \mathrm{mM}$ carbonate buffer, $\mathrm{pH} 9.6$ for 2 hours at $37^{\circ} \mathrm{C}$. After washing three times with PBS-T, the plates were incubated with $3 \%$ skimmed milk in PBS-T for 30 minutes. Thereafter, extracts were deposited to each well and incubated for 2 hours at $37^{\circ} \mathrm{C}$. IgGs anti-RYMV conjugated with alkaline phosphatase diluted in extraction buffer containing $1 \%$ skimmed milk were incubated for 2 hours. The substrate (p-nitrophenylphosphate) was diluted $(1 \mathrm{~g} / \mathrm{ml})$ in $10 \%$ diethanolamine, $\mathrm{pH}$ 9.8. Absorbance was recorded at $405 \mathrm{~nm}$ after $1 \mathrm{~h}$ substrate incubation using a multiscan 
Table 1. Biological and serological detection of RYMV in rice and wild grass.

\begin{tabular}{ccccc}
\hline Plant Species & Sample number & Suspected symptoms $\mathbf{s}^{\mathrm{a}}$ & $\begin{array}{c}\text { Mechanical } \\
\text { transmission }\end{array}$ & $\begin{array}{c}\text { Serological } \\
\text { detection }\end{array}$ \\
\hline Acroceras zizanioides & 8 & $\mathrm{YM}$ & $0 / 8^{\mathrm{b}}$ & $0 / 8$ \\
Echinochloa cholona & 13 & $\mathrm{GM}$ & $0 / 13$ & $0 / 13$ \\
Eragrostis japonica & 3 & $\mathrm{YM}$ & $0 / 3$ & $0 / 3$ \\
Imperata cylindrica & 23 & $\mathrm{YM}$ & $0 / 23$ & $0 / 23$ \\
Leersia hexandra & 22 & $\mathrm{M}$ & $0 / 22$ & $0 / 22$ \\
Sacciolepis africana & 8 & $\mathrm{M}$ & $0 / 8$ & $0 / 8$ \\
Leptochloa caerulescens & 5 & $\mathrm{GM}$ & $0 / 5$ & $0 / 5$ \\
Paspalum vaginatum & 3 & $\mathrm{M}$ & $0 / 3$ & $0 / 3$ \\
Oryza eichingeri & 28 & $\mathrm{M}$ & $0 / 28$ & $0 / 28$ \\
Oryza satival glaberrima & 208 & $\mathrm{YM}$ & $201 / 208$ & $201 / 208$ \\
Rottboellia exaltata & 3 & $\mathrm{M}$ & $0 / 3$ & $0 / 3$ \\
\hline
\end{tabular}

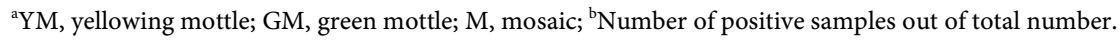
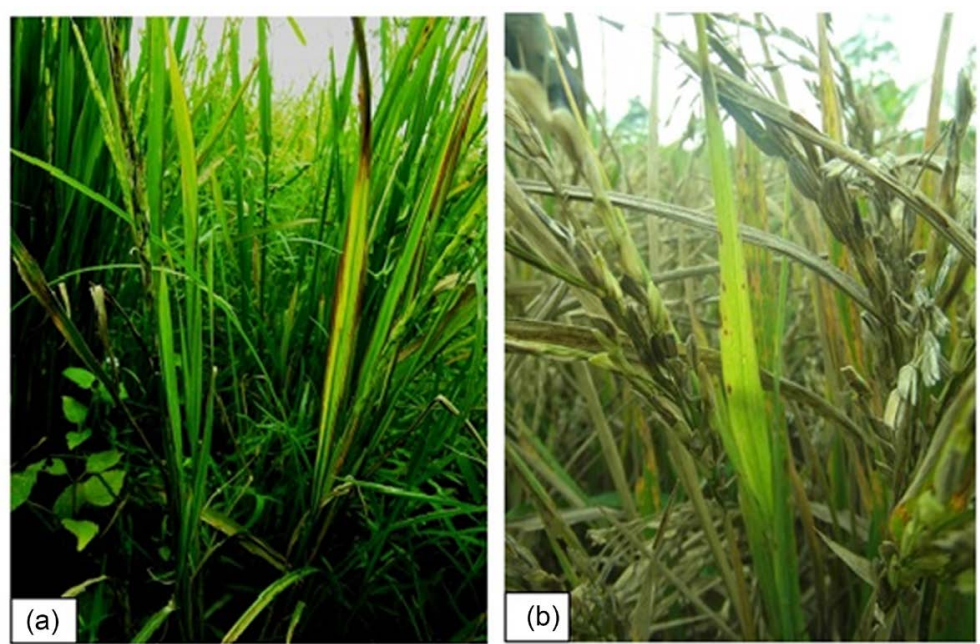

Figure 2. Symptoms of Rice Mottle Disease in field. (a): necrosis; (b): mottle yellowing and sterility of flowers (Picture, R. D. S. Longué, 2015).

microplate reader Metertech $\sum 960$ model. For the whole procedure, each step was followed from washing the plate three times with PBS-T excepted blocking step (skimmed milk incubation step).

\subsection{Serological Typing}

For immunological typing, triple antibody sandwich-ELISA (TAS-ALISA) procedure was performed to determine the serological profiles of RYMV isolates which were detected positive with both biological and serological detection. So, 45 isolates chosen according to sites of provenance were used. Two monoclonal antibodies were used (Mab A and Mab D) to distinguish Ser1 from Ser2 [6] [7]. Thus, the procedure was the same 
as described above with two differences: after leave extracts incubation, monoclonal antibodies were incubated followed by the incubation of Goat anti mouse IgGs conjugated with phosphatase alkaline (GAM-PAL).

\subsection{Statistical Analysis}

In order to test a possible relationship between cultural practices and RYMV occurrence in rice fields, the Chi-square independence test with Yates continuity's correction was used using R statistical software https://www.r-project.org/.

\section{Results}

\subsection{Identification of RYMV in Plant Samples}

For biological detection, typical symptoms of RYMV were induced on susceptible rice variety IR64 only by samples belonging from cultivated rice (Table 1). Up to 96\% (201 out of 208) of leaves samples induced the characteristic yellow discoloration and mottling of leaves (as shown in Figure 2) after mechanical inoculation between 7 and 10 day after inoculation (DAI). By contrast, all samples collected from wild grasses did not infected IR64 for 30 DAI. In addition, the immunological detection using polyclonal antibodies showed positive reactions with all leave samples which were positive at biological test. The positive reaction including positive control ranged from 0.851 and 2.35. Absorbance between 0.028 and 0.2 were attributed to negative samples as they corresponded to the negative control. Negative samples were those from wild grasses. Failure to detect RYMV in these samples suggested that symptoms observed on collected wild grasses were not due to infections by RYMV.

Taking account of the ecology from which samples were collected and cultural practices, we found that infection rates depended on rice growing practices i.e. whether rice was directly seeded or seedlings were transplanted from pre-established seedbeds. Infection rates were significantly higher with transplantation (94.2\%) than with direct seeding (22.8\%) according to Chi-square test $\left(\chi^{2}=108.83, \mathrm{df}=1, \mathrm{P}<0.001\right)$. This indicates that cultural practices, such as transplantation, likely play a role in spread of the disease in the field. However, as shown in Table 2, in both upland and lowland rice fields where direct seedlings were performed, few positive samples were detected.

\subsection{Serological Characterization}

The serological profile of RYMV isolates tested with monoclonal antibodies was homogenous. Indeed, all tested isolates were reacted strongly with Mab A and failed to react with Mab D. The virus titers estimated through absorbance values ranged from 1.063 to 2.628 with an average of $1.909 \pm 0.360$ (average \pm standard deviation, $\mathrm{n}=45$ ) for Mab A and from 0.018 to $0.296 \pm 0.069$ with an average of 0.115 (average \pm standard deviation, $\mathrm{n}=45$ ) for Mab $\mathrm{D}$ (Figure 3). The positive controls of both Mabs had similar absorbance with average of $1.774 \pm 0.525$ and $1.675 \pm 0.346$ for Mabs A and D respectively. This suggested that all isolates belonged to Ser1 serotype, thus RYMV is not diversified at serological level into this region. 
Table 2. Identification of RYMV according to cultural practices and agro-ecosystem.

\begin{tabular}{ccccc}
\hline Locality & Number of samples & Ecology & Cultural practice & Detection $^{\mathrm{a}}$ \\
\hline Bimon & 8 & Lowland & Direct seeding & - \\
Bocaranga & 3 & Upland & Direct seeding & - \\
Bozoum & 4 & Irrigated & Transplantation & - \\
Boyali & 5 & Upland & Direct seeding & - \\
Kapou & 10 & Lowland & Direct seeding & + \\
Ndjim & 2 & Lowland & Direct seeding & + \\
Ngola & 87 & Irrigated & Transplantation & + \\
Ngoulanga & 5 & Lowland & Transplantation & + \\
Pissa & 6 & upland & Direct seeding & + \\
PK10 & 4 & Lowland & Transplantation & + \\
Sabiri & 8 & Lowland & Transplantation & + \\
Sakaï & 59 & Irrigated & Transplantation & + \\
\hline
\end{tabular}

${ }^{\mathrm{a}}+$ and - for positive and negative reactivity respectively.

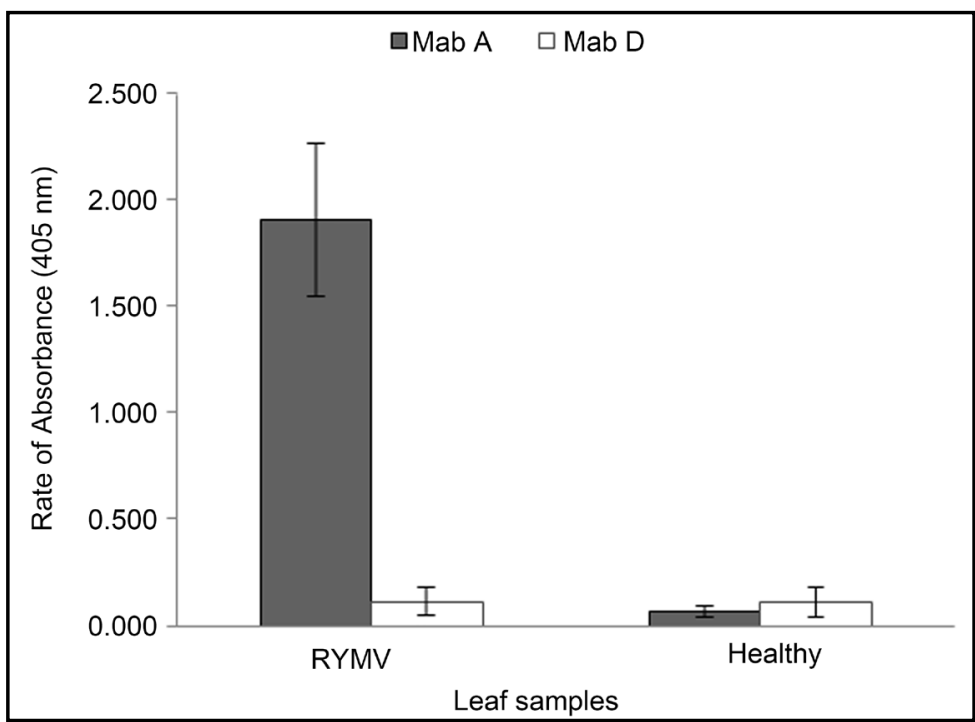

Figure 3. Serological profile of isolates of RYMV from CAR using monoclonal antibodies A and D.

\section{Discussion}

In the Central African region (Cameroon and Chad), RYMV was identified for the first time in 2001 as described by Traoré et al. [15]. Afterward, RYMV was observed in irrigated rice field around Bangui city in Central African Republic a ten years ago [4].

In this study, we investigated the presence of RYMV into several different rice growing sites and analyzed the diversity at serological level using both polyclonal and monoclonal antibodies. 
Our results revealed that 201 leaf samples from cultivated rice exclusively, were detected positive in DAS-ELISA test with absorbance values between 0.851 and 2.35. By contrast, not any sample from wild grasses was positive by serological detection $(0.024$ $<$ A405 nm < 0.3). This was confirmed by mechanical transmission test where no sample could reproduce symptoms of yellowing and mottling. Indeed, only leaf samples which were detected positive at serological level induced characteristic symptoms of rice yellow mottle disease.

Contrary to other reports [8] [12] [16], our results indicated that Echinochloa colona (from Poacea family) is not susceptible to RYMV, confirming the results reported in Est Africa [17]. Moreover, it also has been demonstrated that this species is not host by inoculation to seedlings [18]. However, some wild grasses were found to be host of RYMV such as Leersia hexandra [16] unlike our results. The symptoms observed on Imperata cylindrical were more similar to those of rice yellow mottle disease. The non-detection of RYMV in this species suggested that these symptoms may be probably due to Imperata yellow mottle virus, a Sobemovirus closely related to RYMV [19] which were found in West Africa [20].

Apart from rice cultivated species (Oryza sativa L. and O. glaberrima Steud), the natural host range of RYMV includes a few wild rice species and other Poaceae family. Therefore, the non-detection of RYMV from $O$. eichingeri (forest wild rice species) which is the main wild rice species found into lowland and irrigated system suggested that these symptoms observed belonged to other disease. There is probably that this rice species be resistant to RYMV, because the inoculated seedlings and the back inoculation to susceptible rice cultivar have never induced symptoms (data no shown). Nevertheless, inoculation tests in Kenya with RYMV did not infect this forest wild rice $O$. eichingeri [1].

Like wild grasses may be important in the epidemiological aspects, we suggested that artificial host range could be investigated.

Our result shows clearly that the main natural host of RYMV remains the cultivated rice. In addition, the good observation of symptoms in field can be the first detection of rice yellow mottle disease which may be confirmed by serological detection.

\section{Conclusions}

Results obtained in this study show that 201 isolates of RYMV were detected. All isolates detected positively proceed from samples collected to cultivated rice exclusively. RYMV was only found in the south of the country in the irrigated and lowland rice crops. In addition, farmer cultural practices could play important role in the spread of the disease. At the northwest of the country where most rice is growing, RYMV is suspected but an important survey could be done for identification of the virus in this area.

At the natural hosts level, none species were identified as host of RYMV, because all samples collected from wild grasses were negative in both biological and serological tests. Consequently, it would be interesting to look artificial hosts to better guide the natural hosts identification. 


\section{Acknowledgements}

This study was supported financially by the International Foundation for Science (IFS) through fellowship No. C/5359-1 to R D Longué Sokpé. We are also grateful to SCAC from the French Embassy in Bangui (CAR) for supporting financial my stay in Burkina Faso.

\section{References}

[1] Bakker, W. (1970) Rice Yellow Mottle, a Mechanically Transmissible Virus Disease of Rice in Kenya. Netherlands Journal of Plant Pathology, 76, 53-63. https://doi.org/10.1007/BF01974433

[2] Abo, M.E., Sy, A. and Alegbejo, M.D. (1998) Rice Yellow Mottle Virus (RYMV) in Africa: Evolution, Distribution, Economic Significance on Sustainable Rice Production and Management Strategies. Journal of Sustainable Agriculture, 11, 51-58.

[3] Kouassi, N.K., N’Guessan, P., Albar, L., Fauquet, C.M. and Brugidou, C. (2005) Distribution and Characterization of Rice Yellow Mottle Virus : A Threat to African Farmers. Plant Disease, 89, 124-133. https://doi.org/10.1094/PD-89-0124

[4] Longué, D.R.S., Galzi-Pinel, A., Semballa, S., Zinga, I. and Fargette, D. (2014) First Report of Rice Yellow Mottle Virus in Rice in Central African Republic. Plant Disease, 98, 162. https://doi.org/10.1094/PDIS-04-13-0418-PDN

[5] Sarra, S. and Peters, D. (2003) Rice Yellow Mottle Virus Is Transmitted by Cows, Donkeys, and Grass Rats in Irrigated Rice Crops. Plant Disease, 87, 804-808. https://doi.org/10.1094/PDIS.2003.87.7.804

[6] N'Guessan, P., Pinel, A., Caruana, M., Frusto, R., Sy, A., Ghesquière, A. and Fargette, D. (2000) Evidence of the Presence of Two Serotypes of Rice Yellow Mottle Sobemovirus in Côte d'Ivoire. European Journal of Plant Pathology, 106, 167-178. https://doi.org/10.1023/A:1008792109954

[7] Fargette, D., Pinel, A., Halimi, H., Brugidou, C., Fauquet, C. and Van Regenmortel, M. (2002) Comparison of Molecular and Immunological Typing of Isolates of Rice Yellow Mottle Virus. Archives of Virology, 147, 583-596. https://doi.org/10.1007/s007050200008

[8] Konate, G., Traore, O. and Coulibaly, M.M. (1997) Characterization of Rice Yellow Mottle Virus Isolates in Sudano-Sahelian Areas. Archives of Virology, 142, 1117-1124. https://doi.org/10.1007/s007050050146

[9] Johnson, D.E. (1997) Les Adventices En Riziculture En Afrique de l'Ouest; Weeds of Rice in West Africa. Imprint Design, Côte d'Ivoire.

[10] Abo, M.E., Ukwungwu, M.N. and Onasanya, A. (2002) The Distribution, Incidence, Natural Reservoir Hosts and Insect Vectors of Rice Yellow Mottle Virus (RYMV), Genus Sobemovirus in Northern Nigeria. Tropicultura Journal, 20, 198-202.

[11] Séré, Y., Onasanya, A., Afolabi, S. and Abo, E.M. (2005) Evaluation and Potential of Double Immunodifusion Gel Assay for Serological Characterization of Rice Yellow Mottle Virus Isolates in West Africa. African Journal of Biotechnology, 4, 197-205.

[12] Traoré, O., Traoré, E.V.S., Gumedzoé, M.Y.D. and Konaté, G. (2008) Serological Diagnosis of Sudano-Sahelian Isolates of Rice Yellow Mottle Virus (RYMV). Tropicultura, 26, 74-77.

[13] Traoré, O., Pinel, A., Hebrard, E., Gumedzoé, Y.D., Fargette, D., Traoré, A.S. and Konaté, G. (2006) Occurence of Resistance-Breaking Isolates of Rice Yellow Mottle Virus in West and Central Africa. Plant Disease, 90, 259-263. https://doi.org/10.1094/PD-90-0259

[14] Clark, M.F. and Adams, A.N. (1977) Characteristics of the Microplate Method of Enzyme- 
Linked Immunosorbent Assay for the Detection of Plant Viruses. Journal of General Virology, 34, 475-483. https://doi.org/10.1099/0022-1317-34-3-475

[15] Traoré, O., Pinel, A. and Konate, G. (2001) First Report and Characterization of Rice Yellow Mottle Virus in Central Africa. Plant Disease, 85, 920.

https://doi.org/10.1094/PDIS.2001.85.8.920A

[16] Issaka, S., Basso, A., Sorho, F., Onasanya, A., Haougui, A., Sido, A.Y., Fargette, D. and Séré, Y. (2012) Diagnosis and Importance of Rice Yellow Mottle Disease Epidemics in Niger Republic. Mali Niger Burkina Faso Nigeria. Journal of Applied Biosciences, 50, 3501-3511.

[17] Bakker, W. (1974) Characterization and Ecological Aspects of Rice Yellow Mottle Virus in Kenya Characterization and Ecological Aspects of Rice Yellow Mottle Virus in Kenya. Agricultural Research Reports 829, Wageningen, 1-152.

[18] Allarangaye, M.D., Traoré, O., Traoré, E.V.S., Millogor, J.R., Guinko, S. and Konaté, G. (2007) Host Range of Rice Yellow Mottle Virus in Sudano-Sahelian Savannahs. Pakistan Journal of Biological Sciences, 10, 1414-1421. https://doi.org/10.3923/pjbs.2007.1414.1421

[19] Sõmera, M., Sarmiento, C. and Truve, E. (2015) Overview on Sobemoviruses and a Proposal for the Creation of the Family Sobemoviridae. Viruses, 7, 3076-3115. https://doi.org/10.3390/v7062761

[20] Sérémé, D., Lacombe, S., Konaté, M., Pinel-Galzi, A., Traoré, E.V.S., Hébrard, E., Brugidou, C., Fargette, D. and Konate, G. (2008) Biological and Molecular Characterization of a Putative New Sobemovirus Infecting Imperata cylindrica and Maize in Africa. Archives of Virology, 153, 1813-1820. https://doi.org/10.1007/s00705-008-0190-y

Submit or recommend next manuscript to SCIRP and we will provide best service for you:

Accepting pre-submission inquiries through Email, Facebook, LinkedIn, Twitter, etc. A wide selection of journals (inclusive of 9 subjects, more than 200 journals)

Providing 24-hour high-quality service

User-friendly online submission system

Fair and swift peer-review system

Efficient typesetting and proofreading procedure

Display of the result of downloads and visits, as well as the number of cited articles

Maximum dissemination of your research work

Submit your manuscript at: http://papersubmission.scirp.org/

Or contact as@scirp.org 